TITLE:

\title{
Recollection of Nishida-san: His Days at the University of Tokyo
}

\author{
$\operatorname{AUTHOR(S):~}$
}

Ohtsuka, Ryutaro

\section{CITATION:}

Ohtsuka, Ryutaro. Recollection of Nishida-san: His Days at the University of Tokyo. Pan Africa News 2011, 18(special issue): 4-5

ISSUE DATE:

2011-09

URL:

http://hdl.handle.net/2433/147291

RIGHT:

Copyright (C) Pan Africa News. 
ried the lady, Miss Haruko Kitayama. So for marriage, he again left me behind.

I vaguely believed that I would precede him in only one thing: entering the next world, for I have indulged in over-eating and over-drinking wherever I stayed, in Japan, Africa or the Amazon, without learning anything. That contrasted greatly with Nishida-san, but he preceded me even in this.

For me, he was an invaluable and truly great friend.

May his soul rest in peace.

(English translation by Noriko Itoh)

\section{Short Tribute to Prof. Toshisada Nishida}

\author{
William C. McGrew \\ Cambridge University, UK
}

Many will write of his scientific and academic achievements, which were great and many. Others will write of his commitment to Mahale, its chimpanzees, and its conservation. Here I wish to recall the pleasure of his company and his friendship, in a couple of personal memories:

Only three primatologists attended both WennerGren meetings on The Great Apes (1974, Burg Wartenstein, Austria; 1994, Cabo San Lucas, Mexico): Prof. Jane Goodall, Prof. Nishida, and myself. At the first one, he and I were almost the youngest persons there; at the second one, we were almost the oldest. We both occasionally enjoyed a celebratory alcoholic beverage. Laurie Obbink reminds me that after dinner on the first night at Cabo, Prof. Nishida bowed politely and asked her, "Please, where can we drink more?" She obliged, and we raised our glasses, more than once.

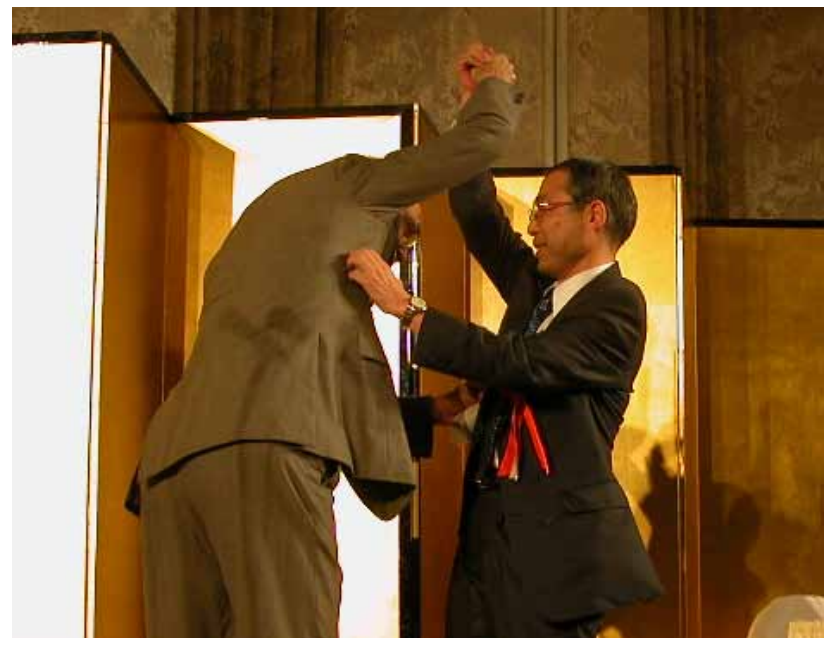

One time during one of the Understanding Chimpanzees conferences in Chicago, I took him to Wrigley Field to see the Cubs play. He admitted to not being a real baseball fan, though he recalled that his father had taken him to games. He paid attention during the play, and was appreciative of the atmosphere of that grand old stadium, but seemed a bit restless. It turned out that what he really wanted to do was stock up on souvenirs, such as baseball hats, pennants, etc., especially to do with Sammy Sosa (a famous Cub homerun hitter of that era). He did so, and we came away, with arms full.

Such are the small memories that never fade.

\section{Recollection of Nishida-san: His Days at the University of Tokyo}

\author{
Ryutaro Ohtsuka \\ Japan Wildlife Research Center, Japan
}

I remember that it was late autumn of 1969 that I met Nishida-san for the first time. He came to see the room of the ecological anthropology group. He had been recently been hired as a research associate in the Department of Anthropology at the University of Tokyo. Nishida-san arrived to take up the position in December of the year, and was promoted to Lecturer and Associate Professor afterwards. He worked in the same department until March, 1988. Thus, he taught at the University of Tokyo for over 18 years, or longer than the period he taught at Kyoto University.

Nishida-san joined the room occupied by the ecological anthropology group, which included the late Dr. Reizo Harako (doctor's course), Dr. Jun Takeda, and me (master's course). Only a few other research students and undergraduate students occasionally spent time in the room, since the ecological anthropology group had just started. We conducted a survey of the fishing communities and matagi hunters, but nobody had investigated the primates. It was only for four months that I was with Nishida-san in the Department of Anthropology, because the following April I became a research associate in the Department of Human Ecology at the University of Tokyo. However, the buildings were near to each other and we met frequently even after that.

Harako-san was a master of the room in the ecological anthropology group. He had been a surgeon but was attracted to the Pygmy people in Africa and was determined to learn anthropology. He was already over 30 years old then. Harako-san was a dominant personality, and Nishida-san was influenced by him. Talking over drinks was one habit instilled in us by Harako-san. At first, Nishidasan did not seem to understand why we went out to drink almost every day, but the frequency with which he joined us gradually increased. In fact, Nishida-san seemed to be more concerned about food than sake. Anyway, he ate a lot. Harako-san also encouraged Nishida-san to play go under his instruction. Nishida-san also became an avid player of the game. I will mention this again later. Let me add that Harako-san had a position of research associate in the Laboratory of Physical Anthropology, Kyoto University, for about eight years beginning in August, 1970.

Nishida-san often took postgraduate and undergraduate students to go to Mt. Takago on the Boso peninsula, Chiba Prefecture, to observe a troop of Japanese macaques, which was not fed by people any more. I also sometimes accompanied them. I remember that Nishidasan changed when he was there: he was full of vitality and walked very fast in the mountains. After Nishida-san began to work in Department of Anthropology, the number of postgraduates who majored in ecological anthropology increased. For instance, Dr. Taizo Iwano and Dr. Mariko Hasegawa (Hiraiwa), who specialized in primate ecol- 
ogy, came to take an active part in the investigation at Mt. Takago.

Let me turn back a little. Nishida-san and I began to collaborate to write books starting in 1972. We worked together to write the "Ecology of Humankind" (Volume 25 of 'The Course of Ecology') of Kyoritsu-Shuppan (collaboration of three people, including Dr. Jiro Tanaka) and in the selection and writing of the items of "animal sociology", "zoogeography", and "human ecology" in the 'Dictionary of Ecology' (Prof. Makoto Numata ed.) of Tsukiji-Shokan. There were three authors of the 'Dictionary of Ecology'; the late Professor Junichiro Itani was the first author, followed by Nishida-san and me. However, we two, Nishida-san and me, came to write it entirely. At one point, we began to meet without the go board to concentrate on writing.

There were various things that I learned from Nishida-san in those days. One was to publish books as well as in journals. First of all, he taught me the importance of conducting original research. We had a strong tendency to put value only on papers at the University of Tokyo, but many people including me came to value the publication of academic books as a result of Nishida-san's influence. Another thing that I learned from Nishida-san is that one's research should make complicated problems easier to understand. This point might reflect, in a sense, a difference in academic traditions between Kyoto University and the University of Tokyo. Anyway, I have always kept this point in mind when collecting data and analyzing them.

While Nishida-san was a Lecturer and an Associate Professor between the 1970's and 1980's, Dr. Tadashi Tanno from the Laboratory of Physical Anthropology at Kyoto University, Dr. Shun Sato, and the late Dr. Satoshi Horai served as research associates in the Department of Anthropology. On the other hand, Harako-san moved to Kyoto University, as mentioned above. All of these personnel changes promoted strong ties between the Laboratory of Physical Anthropology at Kyoto University and the Department of Anthropology and the Department of Human Ecology at the University of Tokyo. Nishida-san kept working hard as a teacher at the University of Tokyo, and as a consequence, there was a surge of interest by students majoring in ecology. Some of them later went on to establish the Association for Ecological Anthropology (The Society for Ecological Anthropology of today).

Finally, let me tell a story about the 11th social gathering of the teachers of the University of Tokyo on February 22, 1988. The president of the University, Wataru Mori, and his special advisor (vice-president) Akito Arima also attended. The theme of the gathering was "Overseas scientific research." Nishida-san talked about his investigations of wild chimpanzees in Africa. I talked about my research on human ecology in Papua New Guinea, and Dr. Masanori Aoyagi of the Faculty of Letters talked about his excavations of archaeological sites of Roman architecture. A campus newsletter at that time described that Nishida-san gave his talk with some touches of humor and that it was received quite well. Thus, Nishida-san left a lasting impact on the development of overseas scientific research at the University of Tokyo, before he left for Kyoto in March.

The end of my recollection is about the game of go, which Nishida-san began to play at the University of Tokyo. We have a lot of lovers of game of go among the members majoring in ecological anthropology in Kyoto

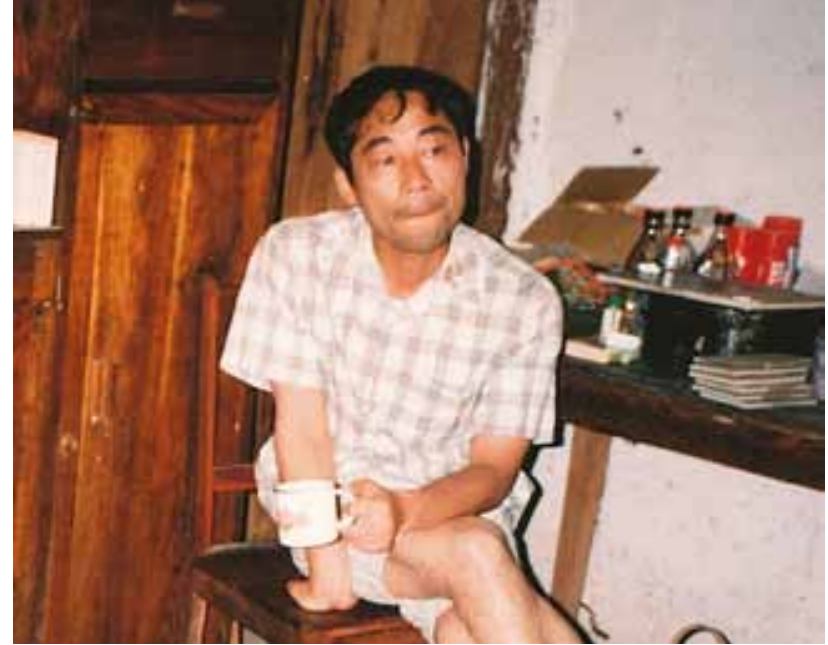

University and the University of Tokyo. We still organize a go tournament twice a year to remember Professor Itani and Harako-san. Of course, Nishida-san was one of the key members. One should be unyielding when playing the game of $g o$, and the unyielding spirit of Nishidasan was considerable. Therefore, it is regrettable that it will not be possible for us to face Nishida-san again at the board. On July 9 this year, we held a "Go tournament in memory of the late Prof. Toshisada Nishida" in Nagoya, and offered condolences in appreciation for his longtime companionship.

Now I put down my pen. On behalf of all his senior and junior colleagues and go companions at the University of Tokyo, I wish to express our sincere gratitude to Nishida-san.

(English translation by Takahisa Matsusaka)

\section{Tribute to Professor Toshisada Nishida}

\author{
Hosea Kayumbo \\ University of Dar es Salaam, Tanzania
}

Professor Toshisada Nishida will be very much missed by staff and students of the Department of Zoology and Wildlife Conservation of the University of Dar es Salaam. He often visited the University of Dar es Salaam on his way to Mahale, Kigoma. He used to interact freely and amicably with staff and students of the Department, to whom he freely gave lectures and conducted seminars. His contributions, however, extend well beyond his role as a mentor.

A quiet but warm, perceptive and acutely intelligent individual, Nishida's lifelong commitment to research on chimpanzees in Africa, stemmed naturally from his interest in people. He particularly emphasised the desirability of engaging with local people. He was very much liked in Mahale. News of his arrival spread quickly throughout the communities living around the National Park. For the field staff who continued to record and collect data while he was in Japan, he would bring many presents - watches, T-shirts, pictures, school books, etc. On one occasion, in August 2001, Professor Kapepwa Tambila, who is from one of the Mahale ethnic (tribes) groups and I accompanied Nishida to Mahale. One evening the local field 